\title{
After the Revolution: State, Civil Society, and Democratization in Armenia and Georgia
}

\author{
Christoph H. Stefes ${ }^{1 *}$ and Yevgenya J. Paturyan ${ }^{2}$ \\ ${ }^{1}$ Department of Political Science, University of Colorado Denver, Denver, Colorado, United States, ${ }^{2}$ College of Humanities \& \\ Social Sciences, American University of Armenia, Yerevan, Armenia
}

In 2003 and 2018, mass protests triggered the collapse of authoritarian regimes in Georgia and Armenia, respectively. In both cases, civil society organizations (CSOs) played an important role in laying the groundwork and organizing the protests. Following the toppling of semi-autocratic leaders, reform-oriented governments took over in both countries. Yet, the way civil society engaged the new rulers differed considerably. Whereas in Georgia, former civil society leaders were often absorbed into the new government, Armenian civil society has kept its distance from the new political leadership. In this paper, we attempt to explain why state-civil society relations after the revolutions have developed in different directions in these two Soviet successor states. We argue that three conditions explain differences in engagement with the new governments:

OPEN ACCESS

Edited by:

Sonja Grimm,

University of Konstanz, Germany

Reviewed by:

David Aprasidze,

Ilia State University, Georgia

Laura Luciani,

Ghent University, Belgium

*Correspondence:

Christoph H. Stefes

Christoph.stefes@ucdenver.edu

Specialty section:

This article was submitted to

Peace and Democracy,

a section of the journal

Frontiers in Political Science

Received: 02 June 2021

Accepted: 05 August 2021

Published: 25 August 2021

Citation:

Stefes $\mathrm{CH}$ and Paturyan YJ (2021)

After the Revolution: State, Civil

Society, and Democratization in

Armenia and Georgia.

Front. Polit. Sci. 3:719478.

doi: 10.3389/fpos.2021.719478
CSOs pre-revolutionary cooperation with the political opposition, Western governments support for civil society before and after the political transitions, and the degree to which CSOs represent and are rooted in the general public. As a consequence, Georgia's postrevolutionary regime lacked the checks and balances that CSOs usually provide, allowing it to sacrifice democratization on the altar of modernization. In Armenia, in contrast, CSOs have maintained a critical stance and continued to hold the government accountable.

Keywords: civil society, georgia, armenia, democratic consolidation, colored revolution

\section{INTRODUCTION}

In the 1990s, an avalanche of studies on civil society began to fill bookshelves and academic journals. Thirty years later, political scientists seem considerably less interested in the subject. Taking into account the tremendous amount of financial aid and technical assistance Western governments have invested in the development of civil society organizations (CSOs) around the world, it is somewhat surprising, and arguably disappointing, that little work has been done to assess whether that effort has paid off in the long run. ${ }^{1}$ With this study, we undertake a modest attempt to assess how state-civil society relations in two post-Soviet countries have evolved, focusing on CSOs as interlocutors. We are interested in the role that civil society has played during and especially after the toppling of authoritarian regimes.

Our case studies are Armenia and Georgia. Georgia underwent a political transition in 2003/04, the so-called Rose Revolution. Armenia followed 15 years later (Velvet Revolution). In both

${ }^{1}$ We use the terms non-governmental organization (NGO) and civil society organization (CSO) interchangeably throughout this study 
transitions, CSOs played an important role in mobilizing citizens before and during the popular uprisings, resulting in the toppling of the semi-authoritarian regimes of Eduard Shevardnadze (Georgia) and Serzh Sargsyan (Armenia). Our focus is on the aftermath of these transitions. To what degree has civil society played a role in ensuring that the new regimes democratize, making sure that the new political leaderships resist the temptation to change political institutions to fortify their power? In short, has civil society maintained its role as a check on political power after the revolutions?

The answer in the case of Georgia is an unequivocal no. Georgia's most influential CSO leaders switched sides, leaving civil society to assume key political positions in the new regime under President Mikhail Saakashvili. This brain drain provided ample opportunity for the new president to accumulate formal and informal power resources in his hands. In Armenia, civil society has maintained equidistance to the new regime. While it is too early to pass final judgement, especially in light of the recent turmoil in the aftermath of the war in Nagorno-Karabakh, it appears as if Armenia's CSOs are today better positioned than were its Georgian counterparts during the Saakashvili years to maintain their roles as institutions of vertical accountability.

To explain this divergence, several interrelated factors and developments are taken into account. Georgia's CSOs sought proximity to the political opposition several years before the Rose Revolution. Largely decoupled from the larger population and heavily reliant on foreign funding, the formal merger of parts of Georgia's civil society after the transition was merely the formalization of its close cooperation with the erstwhile opposition leaders. While some CSOs and media representatives publicly bemoaned Saakashvili's accumulation of power and general intolerance towards the political opposition, their role was diminished due to the brain drain as well as Western governments decision to fully support the new regime, diverting foreign funding away from CSOs and towards good governance projects directed by the new government.

In Armenia, in contrast, prior to the Velvet Revolution CSOs carefully distanced themselves from both the government and the political opposition. Emphasis on neutrality allowed the CSOs to maintain some credibility in the public's eye and avoid antagonizing the government. Similar to the Georgian case, Armenian CSOs were dependent on Western funding. However, in the decade that preceded the Velvet Revolution, societal mobilization in Armenia deepened, widened, and diversified, making civil society more connected to the broader public, more diverse in its forms of organization, and thereby more representative of a wider spectrum of opinions. After the transition, most CSOs enthusiastically embraced the change in country leadership and engaged with the new government, offering support and expertise. The Velvet Revolution was a window of opportunity to implement the reforms that CSOs had long been advocating for. Some CSO leaders and activists joined Pashinyan's government. Many, however, did not, preferring to advise rather than engage directly. Moreover, a number of CSO members and activists who entered the government either quit or were fired within a year after the
Revolution. Thus, there was some initial brain drain from Armenian civil society, but not to the extent present in Georgia.

We have picked these two cases for two reasons. First, as postSoviet countries, they are both supposed to have suffered equally from the "weak civil society" syndrome (Howard 2003). Indeed, the Soviet legacy of autocratic rule and limited societal space hampered civil society development in the wake of the Soviet Union's collapse. However, the breakdown of Soviet rule was 30 years ago. Since then, societal structures have evolved, and it is likely that they have done so in different ways. It is therefore a worthwhile endeavor to analyze the factors that have shaped the diverging trajectories.

Second, picking Georgia and Armenia allows us to adopt a most-similar system design. As neighbors, they share a long list of commonalities, starting with their geographic location, Christian roots, and their long history of being overrun by powerful empires such as Persia, Greece, and Russia, to name just a few (Stefes 2006, Chap. 2). Two variables important for this study are however distinct. For one, Georgia has been somewhat of a darling of Western democracy promotion, Armenia considerably less so. Furthermore, Armenia's post-Soviet regime was more repressive, especially in the years leading up to the Velvet Revolution, than the regime under President Eduard Shevardnadze, a soft authoritarian leader. We would therefore conclude that Georgia's civil society should have been in a much better position to be a democratic force than Armenia's civil society. That was decidedly not the case, which is a puzzle we try to solve. To do so, we rely on qualitative and quantitative data which we have extracted from both primary and secondary sources over the course of more than 2 decades. The authors have continuously conducted field research in both countries since the late 1990s. This research has included dozens of interviews with leading representatives of the state apparatus and civil society in both countries. The findings were published in several publications (e.g., Stefes 2002; Stefes, 2006; Paturyan 2020). As in their previous studies, the authors employ a process-tracing method, highlighting important decision knots and carefully discovering the reasons why these two countries took one path and not another at these critical moments of their political trajectories after the collapse of the Soviet Union.

At the end of this study, we walk away with three conclusions. First, to fulfill its crucial role in helping to move a country along a democratic path, civil society needs to maintain a healthy distance from the regime. It is in the interest of regime leaders to coopt potential checks on their power (Schmotz, 2015). Whenever regime leaders succeed in these cooptation efforts, civil society's role as an institution of vertical accountability weakens. Second, an accurate assessment of civil society's robustness cannot stop at counting the number of CSOs. It has to include at least two variables: 1) the degree to which CSOs are rooted in the general public; and 2) the degree to which civil society is coopted by the regime. Finally, if Western governments are truly interested in strengthening civil society abroad, they have to ensure that CSOs build roots in the larger public and that they are not being coopted by the political leadership. 


\section{CIVIL SOCIETY AND DEMOCRACY}

Civil society is generally defined as a sphere of formal and informal organizations, occupying space between the state, the market, and the lives of individual citizens. In the domain of civil society, people engage in collective action for common goals, based on principles of voluntarism, pluralism, and tolerance (Cohen and Arato 1994; Linz and Alfred Stepan 1996; Diamond 1999; Anheier 2004; Malena and Heinrich 2007; Edwards, 2013; Salamon et al., 2017). The word "civil" suggests a normative connotation in contrast to "uncivil" society that includes groups and organizations advocating extremist ideas or using violence (Kopecký and Mudde, 2003). Such groups are conceptually excluded from civil society, which is supposed to be peaceful and largely law-abiding (Diamond, 1999; Edwards, 2013). ${ }^{2}$

Although common definitions of civil society delineate it from the market and the state, both of these distinctions are disputed in the literature. Some authors point out that the concept of civil society was shaped by the 18th century Scottish Enlightenment thinkers who discussed independent economic actors as much as they discussed civic associations (Keane, 2005). Following this tradition some scholars argue that market-oriented organizations, such as industry associations, should be included in civil society (Fowler 1997; Mazlish 2005). In this paper, we conceptualize civil society as distinct from the market because that is the case in Armenia and Georgia where the legal frameworks regulating CSOs clearly distinguish for-profit from nonprofit organizations.

The questionable delineation and the uneasy relationship between the state and civil society is the focus of this paper. To what extent can civil society be truly independent from the state or distinct from the political realm? A critical (also called radical or neo-Marxist) approach to civil society, inspired by Gramsci, views civil society as unavoidably linked with the state and political organizations (McIlwaine 1998; Lewis 2001). According to this approach, civil society can never be neutral. It is either a tool for the state to extend its influence, a space of anti-state resistance, or both of these simultaneously, making it an arena of clashing powers. Many scholars with a less radical view of civil society also stress that, in practice, the boundary between the state and the civil society is fluid, with the gray zone in between sometimes referred to as "political society" (Edwards 2013). Civil society and the state are interdependent (Edwards 2013). However, to study the impact of one on the other, we conceptually need to demarcate them.

Does civil society influence the state, or does the state influence civil society? This sounds like a "hen and egg" type of question, both sides of it explored by prominent scholars. While Putnam's work (Putnam et al., 1994) focuses on how civic community traditions influence state performance, Skocpol (1999) uses

\footnotetext{
${ }^{2}$ There can be exceptions to the expectation of civil society respecting the rule of law in a given country, such as acts of civil disobedience and conscientious breaking of laws considered to be unjust
}

historic records of US associational life to build the opposite argument of how newly created American state structures and regulations helped create vibrant associational life. This paper discusses state-civil society relations with a focus on how civil society can strengthen democratic institutions, serving as a crucial component of vertical accountability.

The idea that voluntary associations contribute to democracy dates back to Alexis de Tocqueville's seminal work on the organization of Western settlers in the United States [Tocqueville, 2007 (1864)]. The broader (and more complex) term "civil society" was popularized by Eastern European dissidents in the late 1970s and in the 1980s (Cohen and Arato 1994). Václav Havel wrote about civil society as a source of public resistance to oppressive Communist states (Myant, 2005). After the collapse of the Eastern Bloc, civil society was hailed by many democratization scholars (Cohen and Arato 1994; Linz and Alfred Stepan 1996; Diamond 1999) and development practitioners as the harbinger of democratic transition and consolidation in the post-communist region and the world at large.

International development organizations, such as the World Bank, the United Nations Development Programme, and the United States Agency for International Development embraced the concept (Mcllwaine 1998) and provided generous funding for strengthening CSOs. Influenced by neo-Tocquevillian liberal emphasis on voluntary associations and looking for tangible entities to support, the development industry primarily focused on non-governmental and nonprofit organizations (Lewis 2001; Mandel 2012). Spurred by foreign funding (but also restricted by donor-imposed institutional formats and expectations), professionalized NGOs grew like mushrooms, often replacing local traditions of self-organization and mobilization (Voicu and Voicu 2003; Ishkanian 2008; Aliyev, 2015; Knox and Yessimova 2015).

Scholars interest in civil society is based on both theoretical considerations of what civil society can do, and empirical studies of its accomplishments. Civil society can help undermine nondemocratic regimes and push for democratic transitions (Bernhard, 1993; Geremek, 1996; Karatnycky and Ackerman, 2005; Beissinger, 2007). After the transition, civil society can play various roles in democratic consolidation (Diamond, 1999; Carroll and Carroll, 2004; Tusalem, 2007). These roles can be grouped into two broad categories of external effects that describe the impact of CSOs on the regime, and internal effects that refer to the impact that civil society has on its members (Henderson, 2002; Howard, 2003; Putnam et al., 1994, 90).

External effects of civil society refer to the ability of CSOs to advance democracy by informing the public debate, representing citizens interests, preventing regimes to abandon the democratic project, directly participating in governance, and a range of explicitly pro-democratic projects, implemented by CSOs (Diamond, 1999; Warren, 2001; Fung, 2003). Cohen and Arato, (1994) and Habermas, (1996) argue that facilitating public deliberation is one of the most important democratic functions of civil society. CSOs draw public attention to issues like human rights abuses, compliance with laws and so on. Through information campaigns, court litigation, organization 


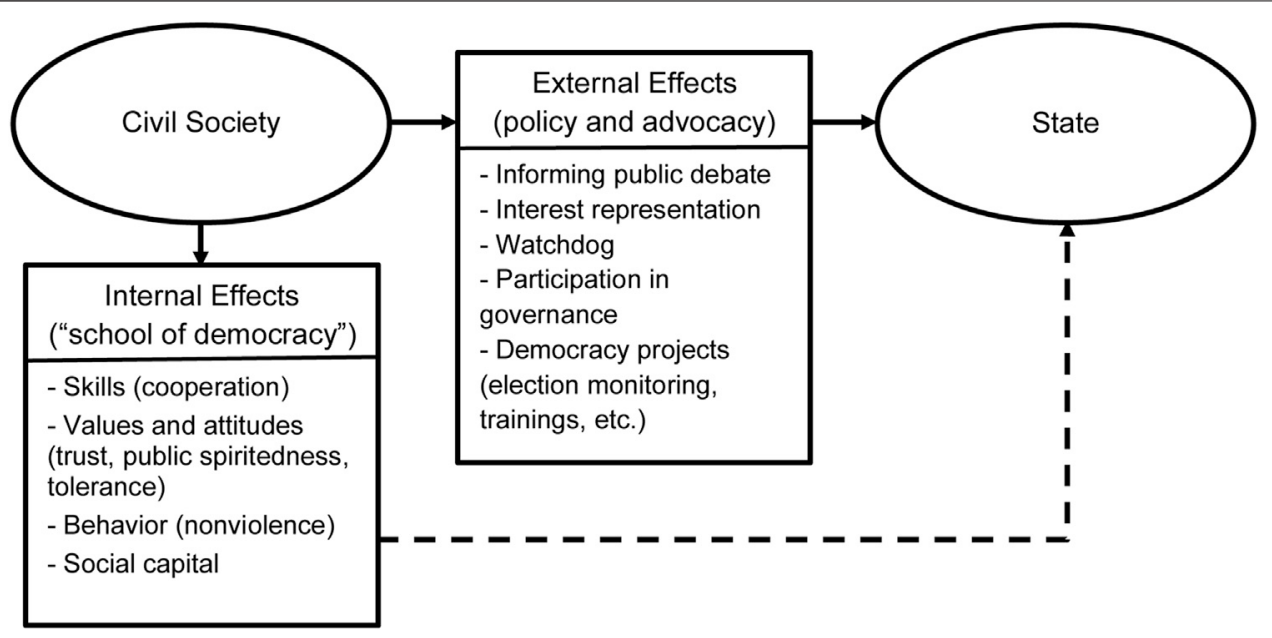

FIGURE 1 | Internal and External Effects of Civil Society on State Democratic Consolidation.

of protests and a range of other activities, civil society monitors and restrains the state, holding it accountable. Various (sometimes competing) civil society groups engage in advocacy and lobbying, enriching the public discourse, strengthening representation of diverse interests, providing the government with niche expertise, and pushing for reforms. Sometimes CSOs become directly involved in planning or implementing policies in the spirit of participatory democracy (Fung, 2003). External democratic effects of civil society also include education for democracy (training and teaching materials for participatory democracy, citizenship, rights, etc.), conflict mediation, and monitoring elections (Diamond 1999).

Internal effects of civil society refer to the ways CSOs socialize the general public in democratic ways. Direct and indirect involvement in the activities of the CSOs is expected to strengthen democratic knowledge, skills, attitudes, values, and behavior (Warren 2001). CSOs are supposed to serve as "schools of democracy" (Verba et al., 1995; Moyser and Parry, 1997; Fung, 2003) where people meet and decide on matters of common interest, thus developing habits of cooperation and publicspiritedness. Civil society often brings together people from different walks of life, exposing individual members to diverse opinions and experiences, helping people to build bridges beyond their narrow social circles. This creates social capital (Coleman, 1990; Putnam 2000), enabling collective action, but also helps people develop tolerance for diversity, respect for opposing viewpoints, and willingness to compromise (Diamond 1999). A pluralistic civil society "tends to generate a wide range of interests that may cross-cut, and so mitigate, the principal polarities of political conflict" (Diamond, 1999, 245). Theoretically, this should help consolidate democracy, since the latter requires informed, tolerant, engaged, and sophisticated citizens. Unlike the external effects of civil society on the state, the internal effects are often indirect, less visible, and take longer time to materialize. Figure 1 summarizes civil society's possible internal and external effects on the state and the process of democratic consolidation.
Empirical evidence of positive external and internal effects of civil society on developing democracy is rather mixed. In established democracies, active civic communities pressure governments to deliver better services (Warren, 2001; Welzel et al., 2005; Tavits, 2006). Case studies from various parts of the world show active engagement of civil society in various policy areas (Berry, 1999; Clemens, 1999; Carroll and Carroll, 2004). Yet, there is also daunting counter-evidence of vibrant civil society undermining democracy by deepening existing conflicts (Bieber, 2003; Kaldor et al., 2007) or supporting autocratic leaders (Berman, 1997; Hemment, 2012). Critical approach to civil society questions neoliberal assumptions of civil society as inherently good for democracy. It discusses some of its negative consequences, such as depoliticizing public discourse, coopting grassroots movements, weakening states welfare provision by syphoning away funds, and ultimately undermining state legitimacy by assuming some of the states critical functions (Arellano-López and Petras, 1994; Mercer, 2002; Eliasoph, 2003; Fowler and Biekart, 2013).

In the end, to fulfill its internal and external roles, civil society needs to keep a healthy distance from the state. While some cooperation with the state is likely desirable to enhance governance, it is also clear that CSOs that have become too dependent on the state are unlikely to expose regime wrongdoings. Furthermore, CSOs that are only loosely rooted in the general public will not be able to contribute much to democratic socialization. Finally, CSOs that are merely extensions of the state apparatus are unlikely to generate much trust among the general public.

While academics are still debating the merits of civil society, the international development industry and policymakers has increasingly become skeptical. At the start of the 21st century, it has become clear that civil society is not a magic bullet to turn authoritarian regimes into viable democracies. Despite extensive and rather convincing theoretical arguments of the importance of civil society for democratic development, the empirical reality "on 


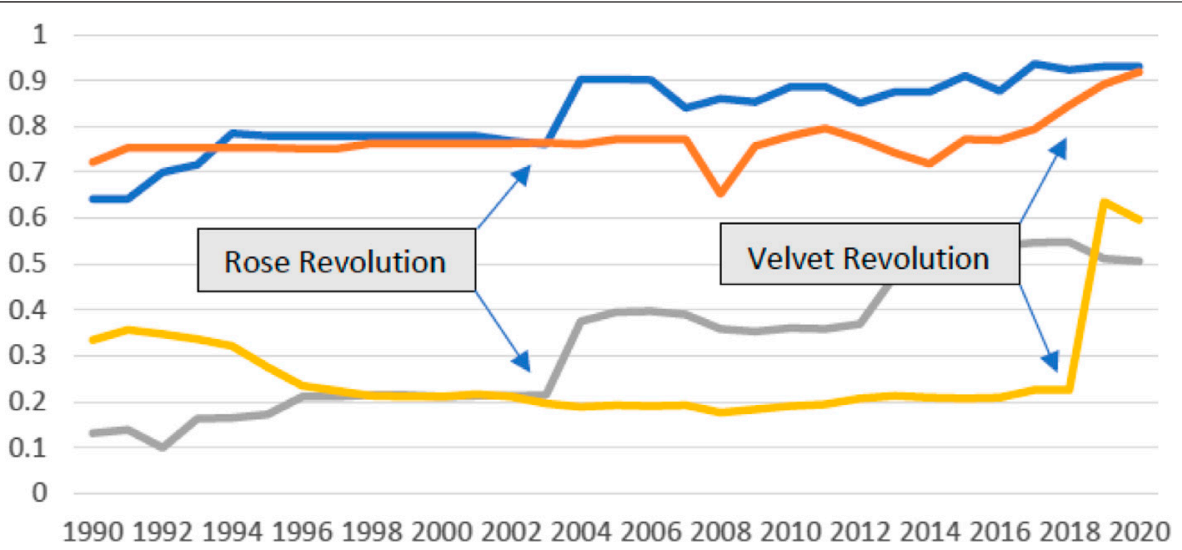

$\longrightarrow$ Georgia CS Armenia CS Georgia (ELD) Armenia (ELD)

FIGURE 2 | Civil Society Robustness and Democracy.

the ground" fell short of many expectations. Some reasons will be addressed in this paper.

\section{CASE STUDIES}

\section{A. Overview}

In the following, we will look closer at the degree to which civil society has been able to bolster democratic institutions in our two countries, and why the external and internal effects of civil society on democratic developments in Armenia and Georgia have varied following the toppling of authoritarian regimes. We start with a quick overview of the cases. We thereby rely on the Varieties of Democracy (V-Dem Institute, 2021) project to sketch the political developments in our two cases since their independence. In particular, we use its "Core Civil Society Index" (CS) and aggregate its "Electoral Democracy Index" and "Liberal Democracy Index" to synthesize civil society and democratic developments in Armenia and Georgia since the disintegration of the Soviet Union. The developments are summarized in Figure 2.

V-DEM understands a "robust civil society" as "one that enjoys autonomy from the state and in which citizens freely and actively pursue their political and civic goals, however conceived" (Coppedge et al., 2021, 305). V-DEM's Electoral Democracy Index (EDI) and Liberal Democracy Index (LDI) measure the degree to which elections are democratically conducted, and the degree to which civil liberties are protected, respectively (Coppedge et al., 2020, 4). For simplicity's sake, the two indices are aggregated into one index in the graph below (ELD).

In both countries, independence movements provided the foundation for the rise of CSOs in the early post-Soviet period. Yet, Georgia also experienced a more tumultuous transition from Soviet rule than Armenia. Mired in civil and ethnic wars, Georgia in the early 1990s was marked by a breakdown of state authority, the economy, and the country's basic infrastructure. Under these circumstances, civil society development was interrupted. With the return of Georgia's erstwhile First Secretary of the Communist Party, Eduard Shevardnadze, the political and economic situation normalized. Although Shevardnadze's regime (1995-2003) relied heavily on electoral fraud to stay in power, it protected civil liberties to some degree and allowed for a modicum of political competition. With significant Western support, Georgia's civil society consolidated during this time.

Armenia benefitted from a negotiated transition between the Communists and the nationalists, providing opportunities for CSOs to flourish and for democracy to develop (Stefes, 2006, Chap. 2). Yet, under the country's first president, Levon TerPetrosyan who resigned in 1998, democratic institutions were successively undermined, as one major opposition party was outlawed, media freedom was curtailed, and elections were rigged. Under his two successors, Robert Kocharyan and Serzh Sargsyan (both from the same ruling elite, although Kocharyan was formally non-partisan), the protection of political rights and civil liberties saw no improvement, quite the opposite, and civil society development stagnated. V-DEM even recorded a noticeable decline in civil society robustness in the wake of the 2007 parliamentary and 2008 presidential elections which were marred by electoral fraud, sparking widespread regime protests that were brutally repressed. According to V-DEM, civil society appeared to make headway a couple of years before and especially after the Velvet Revolution in 2018 which swept Sargsyan and his ruling party from power. Sargsyan was replaced by Nikol Pashinyan, a former journalist and outspoken critic of the Kocharyan-Sargsyan regime. 2018 marked the end of autocratic rule in Armenia, and V-DEM recorded a significant increase in democratic quality following the Velvet Revolution.

\section{B. Georgia}

Among scholars of the successor states of the Soviet Union, Georgia's civil society was often hailed as vibrant and politically 
influential, especially in comparison to other post-Soviet states such as Azerbaijan, Uzbekistan, and Belarus (Mitchell, 2004; Broers, 2005; Ishiyama et al., 2018). In fact, during most of the 1990s, Georgia's CSOs as well as the media benefited from two key factors. First, the political regime under the leadership of President Eduard Shevardnadze was both too weak and unwilling to repress political rights and civil liberties (Mitchell, 2009, 174). Second, Georgia was a major recipient of Western democracy assistance, most of which went to the country's CSOs and various media outlets (King, 2009, 14). However, Georgia's civil society neither had an easy start, nor was it able to develop deep societal roots. The path it took before the Rose Revolution ultimately weakened its role as a watchdog after the rise of Mikhail Saakashvili and his party, the United National Movement.

In the final years of the Soviet Union, Mikhail Gorbachev's perestroika allowed for the emergence of CSOs with deep roots in the nationalist independence movement. Yet, this movement ultimately failed to provide a foundation for a robust civil society due to the collapse of Georgia's state authority and economy in the wake of the country's independence. During most of the first half of the 1990s, paramilitary and organized crime groups as well as economic hardship stifled civil society development, as V-DEM correctly records in its Core Civil Society Index. The return to power of Georgia's former First Secretary of the Communist Party brought back some normalcy. Shevardnadze skillfully used his former nomenklatura networks to rebuild state authority, stabilize the economy, and solicit Russia's support to broker ceasefires in the country's breakaway regions of South Ossetia and Abkhazia (Stefes, 2006). Georgia's president did so without employing heavy-hand tactics and without turning Georgia into a client state of Russia. The United States and European governments rewarded this pro-Western course with massive reconstruction aid which also benefited the country's civil society. For instance, "In 2000, the US Agency for International Development (USAID) spent US\$200 per person in Georgia compared with US\$1.25 in Russia. The US blanketed Georgia with civic and democracy-building programmes" (Jones, 2006, 41).

Shevardnadze's liberal course and Western aid triggered a massive proliferation of CSOs. For instance, whereas in 1992, no NGO officially existed in Georgia; only 5 years later, 3,000 NGOs were formally registered; and another 5 years later, the number had risen to 5,000 (Jones, 2000, 68; Wheatley, 2010, 4). Some of these NGOs coordinated their activities, regularly met with parliamentarians, international organizations, and journalists, and often consulted with government officials when important bills were under review (Stefes, 2002, 39). Supported by generous Western funding, Georgian NGOs quickly developed their capacity to directly engage with the state, engaging in a range of activities that corresponded to the external effects of civil society on democracy discussed above.

Moreover, the media enjoyed considerable freedom and, with the support of Western organizations, was quite professional. Most Georgians received their news from TV, and the most popular stations, Rustavi two and Imedi, were privately owned and critical of Shevardnadze and his government. Among the print media, 24 Hours was widely read and just like Rustavi 2, it provided critical coverage of the government (Anable, 2006).
Yet, these numbers are somewhat misleading. As Jonathan Wheatley summarizes:

Georgian civil society was not what it seemed. Of the 5,000 or so NGOs, only 600-800 had carried out at least one project and most of these were small and highly dependent on outside donor funding. Only around 200 were considered to be relatively stable and just 20 to 30 had permanent staff and boards (Wheatley, 2010, 4).

Furthermore, CSOs lacked deep roots in Georgia's general public. Formal interest groups were either dormant or nonexisting. Organizations that represented the interests of workers, small business owners, and other occupational groups largely existed on paper only. In a country in which corruption was widespread and systemic, formal interest representation was considered inefficient and even dangerous. To get things done, reliance on clientelist networks and the frequent payment of bribes produced desired results more reliably. In contrast, becoming publicly visible as a registered member of an interest group would likely draw undesired attention from corrupt politicians and bureaucrats (Stefes, 2006, 122).

Civil society therefore consisted largely of organizations that furthered democracy and human rights or, to a lesser degree, provided humanitarian aid. With Western aid propping up these CSOs, they attracted a group of young, well-educated, Englishspeaking, and Western-oriented Georgians, mainly in the country's capital. In Georgia's rural regions, however, CSOs barely existed. As Laurence Broers $(2005,338)$ argues: “The availability of significant external resources for NGO development led to a degree of imbalance between a set of comparatively well-resourced, Anglophone NGOs in Tbilisi and much weaker regional development."

Moreover, this group of activists was relatively small. Since foreign grants were the major source of income for Georgia's CSOs, they had no pecuniary interest in expanding their membership, for that would have spread scarce income sources even wider. "There is a prevalent feeling, for which the civil society organizations themselves are responsible, that they do not want to involve more citizens in their activities as this may cause the redistribution of scarce resources and changes in the balance of influence" (Tevzadze, 2003, 24). Georgian civil society seemingly lacked values and attitudes conducive to internal prodemocratic effects on its members and the broader population. Georgian NGOs did not function as "schools of democracy" that connect the state to the people and the people to each other. Instead, they resembled small consultancy businesses.

What emerged was a "group of professional 'NGO people" (Muskhelishvili and Jorjoliani, 2009, 687) or, what Stephen Jones calls, "a modern 'labour aristocracy" (Jones, 2006, 42). This group was largely detached from society. Most civil society projects did not significantly improve the plight of the general public, which made the latter watch the former with suspicion, calling them "grant eaters" who were on the payroll of the US government or, even worse, the CIA (Tevzadze, 2003, 24). The "grant eaters" in turn looked at the general public with contempt. They considered themselves the avant-garde that would lead the country to a better future. In fact, this mindset "was not specific to this particular group of activists, but was widespread in the political culture, originating to a great extent from the Soviet 
legacy of political leadership by the "vanguard" Communist party" (Muskhelishvili and Jorjoliani, 2009, 687; see also Cheterian, 2008, 705).

As Leven Ramashvili, himself a former NGO activist, selfcritically summarizes:

We just got some alternative nomenklatura, I mean, it was not genuine civil society, because these people were just concerned about their employment and were not accountable to the local community, but to those who gave them money. And that's how the Writers Union operated in Soviet time. Some of these people were fluent in English, but I mean their attitudes were not significantly different from the previous generation of public organization in Soviet time. ${ }^{3}$

Understanding themselves not as the representatives of Georgia's society, but as its leaders, members of the most prominent CSOs naturally sought the proximity to like-minded politicians. Many of these politicians were members of Shevardnadze's party and even of his government. They used cooperation with civil society and Western governments to counterbalance the remnants of the Soviet elite which Shevardnadze had brought into his government. This goal was only partially achieved. The corrupt networks held steady, stalling major political and economic reforms. With the 1999 parliamentary and 2000 presidential elections, a new stage of political struggle was reached.

It should also be noted though that Georgia's civil society did not merely exist of Western-funded NGOs. Georgia's Orthodox Church has likely been the most influential non-state actor since the country's independence. Yet, like other orthodox churches around the world (e.g., in Russia), Georgia's Orthodox Church was not a progressive force. It rarely opposed government leaders, and it focused on the promotion of deeply conservative values. For instance, its hostile stance against Georgia's vibrant LGBTQ community has been notorious. It has thereby been complicit with the violent attacks on participants of a 2021 pride parade and the journalists who covered the event. The violence left numerous campaigners and journalists injured. One journalist died after he was severely beaten (BBC, 2021).

Following the 1999 and 2000 elections, and especially after the murder of a prominent Rustavi two journalist in 2001, the reformers in Shevardnadze's camp such as Saakashvili, Zurab Zhvania, and Nino Burjanadze left the camp of President Shevardnadze and founded two major opposition parties. In turn, the cooperation between reform-minded opposition leaders, the CSO community, and various Western-oriented journalists intensified further (Muskhelishvili and Jorjoliani, 2009, 690). Around this time, CSO leaders realized that they would need the support of the general public to achieve farreaching political change. They had to overcome widespread political lethargy and fear of political violence. ${ }^{4}$ As Ramashvili put it, "networks that we had previously built were absolutely not usable for this new purpose. They were actually quite counterproductive, not usable to mobilize and not interested

\footnotetext{
${ }^{3}$ Interview with Stefes, Tbilisi, 2 July 2012

${ }^{4}$ Giorgi Kandelaki, former leader of the student movement Kmara, in an interview with Stefes, Tbilisi, 2 July 2012
}

in any real change." ${ }^{5}$ Yet, unlike in Armenia, no civic initiatives formed. With the exception of Kmara! (see below), local citizen movements that include more than a handful of activists and with concrete goals have largely been unknown in Georgia since the heydays of the country's nationalist movement in the 1980s. In other words, Georgian civil society was suffering from its feeble connection to the broader public due to its weak ability to produce and harness the internal effects that civil society usually has on democracy.

One of the leading Georgian CSOs, the Liberty Institute, began to mobilize students which loosely organized the movement Kmara! (Enough!), modelled after the Serbian student organization Otpor, which was a key player in the toppling of Serbia's dictatorship in 2000. Otpor activists later provided training in tactics of civil disobedience and nonviolent resistance for Georgian Kmara! leaders. Georgia's CSOs also reached out to the general public. For instance, they organized clean yard campaigns in Tbilisi. At the end of the day, activists would hand out small brochures that encouraged citizens to clean up their garbage today, but their corrupt government tomorrow. ${ }^{6}$ Furthermore, Western donors provided significant funds and training to support the creation of fair election CSOs such as the International Society for Fair Elections and Democracy.

By the time the 2003 parliamentary elections were held, the political opposition, CSO leaders, and independent media outlets had mobilized a sufficient number of people to launch widespread protests in response to electoral fraud. These protests eventually led to Shevardnadze's resignation in November 2003. Whether the fall of Shevardnadze and his regime was indeed due to the strength of the political opposition and civil society or due to the weakness of the repressive state apparatus is merely an academic question (for instance, Bunce and Wolchik, 2009; Way, 2008). In the end, power is relational. The weakness of Shevardnadze's regime was the strength of the opposition and vice versa. What is more relevant for our analysis is the fact that the formal separation between political elite and civil society was abandoned, as numerous civil society leaders, think tank members, and journalists joined Saakashvili's party and state apparatus. Among these key leaders were Vano Merabishvili, former director of Georgia's Landowner Protection League, then Interior Minister in Saakashvili's cabinet; Giorgi Kandelaki, former Kmara! leader, then member of the United National Movement and Member of Parliament; and Giga Bokeria, former director of the Liberty Institute, then successively in several key positions in Saakashvili's government.

This merger of CSO leaders, media representatives, and political elite deprived post-Shevardnadze Georgia of healthy pluralism and any meaningful checks and balances (Broers, 2005, 344; Cheterian, 2008, 698; Jones, 2006, 46; Muskhelishvili and Jorjoliani, 2009, 692; Wheatley, 2010, 4). The United National Movement engaged in "tireless efforts not to eliminate (as in nearby countries), but rather to coopt,

\footnotetext{
${ }^{5}$ Interview with Stefes, Tbilisi, 2 July 2012

${ }^{6}$ Interviews with Nino Gogiberidze, former Kmara activist, Tbilisi, 2 July 2012 and Kandelaki
} 
control, or penetrate key institutions of civil society" (Fairbanks and Charles, 2014, 158). It could do so because CSOs had no deep roots in Georgia's general public.

At the same time, Western funding was diverted away from democracy and civil society promotion towards the Georgian state to assist in good governance projects (Muskhelishvili and Jorjoliani, 2009, 694). As Vicken Cheterian, 2008, (699) summarizes 5 years after the Rose Revolution, Civil society actors came to power with the revolutionary wave, and as a result weakened the pluralism and balance in Georgian politics The already impoverished civil society sector is left with less international support today than it enjoyed previously, and it fails to perform its former function as a hybrid of watchdog and opposition platform.

Saakashvili used his overwhelming popularity and lack of vertical accountability to push through various laws and constitutional amendments that curtailed horizontal accountability, reducing the independence of the judiciary and legislative. In addition, media outlets that had once been quite critical, such as Rustavi 2, muted their critique of the new government, while media outlets that attempted to maintain a critical stance were exposed to government pressure (Fairbanks et al., 2013, 118; Muskhelishvili and Jorjoliani, 2009, 693). Finally, Saakashvili was able to eradicate corruption at the lower levels of government. At the same time, he centralized corruption in his hands by distributing spoils among his friends and followers (Kupatadze, 2016, 116). According to Cheterian, "The reforms undertaken by Saakashvili did not empower citizens and civil society. Rather, they reinforced the state, which recovered the space that was left free under the old regime" (Cheterian, 2008, 703). An "excessive concentration of power" was the result (Kupchan, 2006).

Although a few brave CSO representatives and journalists criticized the president for throttling the political space for civil society and the media, the international community's critique of Saakashvili was relatively muted. Only when the government violently cracked down on peaceful protesters in late $2007 \mathrm{did}$ some Western government officials voice their displeasure. In the end, Saakashvili and the United National Movement did not change course. For them, the modernization of Georgia and not the country's democratization was the key goal (Cheterian, 2008). Nevertheless, the United National Movement conceded defeat in the 2012 parliamentary elections, and 1 year later, Saakashvili observed the two-term presidential limit and stepped down.

Considering the external effects of civil society on democracy, it is clear that Georgia's civil society was less effective under the Saakashvili presidency. Some CSOs maintained their critical stance, drawing attention to human rights issues such as the mistreatment of prisoners. Yet, many CSOs muted their critique when Saakashvili quietly abandoned the democratic project. There was also less Western funding for pro-democracy projects available, depriving CSOs of crucial financial assistance. CSOs remained on the sidelines when mass protests emerged against Saakashvili in 2007/08 which the government brutally repressed.

Even more debilitating was arguably Georgian CSOs wanting rootedness in the larger public. CSOs that are avant-garde organizations have limited internal effects on democracy. They cannot serve as "schools of democracy" when its leaders are mistrusted and considered elitist. They cannot serve as arenas in which social capital is built. For elitist CSOs are relatively empty arenas that only occasionally reach out to the general public to enlist them for their goals.

Developments in recent years have revealed how much the fate of Saakasvhili's government and Georgia's civil society were intertwined. After the fall of Saakashvili and his party, civil society has notably revived and diversified. For the past few years, the "Shame" movement serves as a good example. "Shame" has been led by intellectuals and professionals that belong to the upper middle class of Georgia. It opposes the current government, but strictly engages in peaceful protests. Most noteworthy, it has remained bipartisan, not following politicians, but in some way pushing them. As one activist puts it, "In Georgia, people used to go to demonstrations organized by politicians. What we achieved is that now politicians come to the demonstrations organized by people" (Lomsadze, 2019). Another example is the environmental movement formed by common residents of the upper Rioni River Valley in opposition to the building of a hydropower plant in the valley which threatens to cause the extinction of endangered species, notably extremely rare sturgeons (Jacob 2021).

\section{Armenia}

Like Georgia, Armenian civil society went through several, albeit different, stages of development. Some Armenian authors consider 1988 the birth year of Armenian civil society (Abrahamyan, 2001; Abrahamian and Shagoyan, 2011). Around the end of the Soviet era and during the first years of independence, civil society consisted mostly of informal movements and organizations focused on national issues related to the Nagorno Karabakh movement ${ }^{7}$ and Armenian independence. Humanitarian relief efforts focused on survivors of the 1988 earthquake and on refugees arriving from Azerbaijan as the Nagorno Karabakh conflict escalated (Paturyan and Gevorgyan 2021). Like its Georgian counterpart, the Armenian Apostolic Church commanded deep respect and loyalty of most Armenians. After lifting of Soviet restrictions, the importance of the Church grew dramatically, but it used its authority to mostly support consecutive Armenian governments (Mkrtchya, 2019), albeit not the current post-revolutionary government.

At the outset of the country's independence, the socioeconomic situation in Armenia started to deteriorate rapidly due to the imploding economy and the war with Azerbaijan. While people withdrew from civic activities and focused on daily survival, the CSO sector expanded thanks to international aid

\footnotetext{
${ }^{7}$ Nagorno Karabakh (NK) is an Armenian-populated region that was included in Soviet Azerbaijan. In 1988 NK local Armenian authorities initiated a selfdetermination movement, which quickly spilled over to the Soviet Republic of Armenia, galvanizing the population. Predictably, Azerbaijan reacted with hostilities. Violence ensued. A full-fledged armed conflict, now commonly referred to as the First Karabakh war, lasted until the 1994 ceasefire
} 
(albeit less generous than the aid provided for Georgia's CSOs). Similar to the Georgian case, numbers of CSOs grew rapidly in the 1990s, reaching a similar threshold of about 3,500 formally registered organizations of which about 800 were active (Paturyan and Gevorgyan, 2021, 31-33). During this period, civil society shifted from service delivery to advocacy, positioning itself as the main check on political power. Like the Georgian CSO sector, it thereby focused primarily on democracy and human rights, strengthening its external effects on democracy promotion.

Rapid, donor-driven development of CSOs was described as a "genetically engineered civil society" (Ishkanian, 2009, 10), detached from the larger public and focused on priorities promoted by international development organizations. As in Georgia, Armenian CSOs were derogatorily called "grant eaters" by the public, some government officials, and even some civil society activists (Paturyan and Gevorgyan, 2021, 70-71). Like in Georgia, high levels of corruption further undermined public trust in CSOs, breeding suspicion of possible shady deals between government officials and CSOs. In fact, politicians in both countries created their own NGOs to siphon off international development aid (Stefes, 2006, 123). These factors undermined Armenian civil society's internal democratic effects, hindering its ability to connect to the broader public. However, as we argue below, Armenian civil society was able to (re-)build some of these connections.

Similar to Georgia, a rather professional CSO sector developed in Armenia, gaining valuable experience as watchdogs. It promoted human rights, and it served as a source of expertise, alternative information, and a platform for democratic discourse. CSOs published reports documenting the misuse of public resources, environmental degradation, human rights abuses, and so on. They lobbied for or against legislative proposals, monitored elections, and shed light on election fraud. Given the democratic deficit and weak political opposition, CSOs played an important role in holding the Armenian government accountable at least to some degree.

The government, however, preferred to ignore independent civil society groups and its representatives. Unlike Georgia, Armenia's ruling elites successfully consolidated the state apparatus in the early 1990s and built a cohesive authoritarian regime "which successfully thwarted opposition movements and mass protests on numerous occasions" (Ohanyan, 2020, 38). By 1994, the Armenian government was strong enough to ban an influential political party ${ }^{8}$ and close down its media outlet. By 1996, it was capable of stealing a presidential election and suppressing large demonstrations (Astourian and Stephan, 2000). Unlike Georgia, major media outlets in Armenia remained under government control, whereas the few privately owned TV stations exercised self-censorship. Until the arrival of the Internet, newspapers with tiny readership (around 5,000-7,000 copies, at best) were the only critical media sources (Robson, 2011). Armenia's competitive authoritarian regime was "surprisingly robust" (Broers, 2020, 7). It could

\footnotetext{
${ }^{8}$ Armenian Revolutionary Federation, also known as Dashnaktsutyun
}

comfortably keep civil society at arm's length with occasional small concessions and token engagement through carefully managed bodies, for example, through Public Councils that were created in various government bodies. These councils have largely been ineffective even after the Velvet Revolution (Conference of INGOs of the Council of Europe 2020). Armenian civil society's external effects on democratization were minimal.

Like in Georgia, most CSO members and leaders were welleducated, mostly residing in the capital and advocating proWestern liberal ideas. Some Armenian CSOs were connected to the Armenian diaspora, including the Middle Eastern diaspora organizations, that provided funding and human capital. Young educated Armenians who repatriated to Armenia from Western countries often worked in NGOs, but were not necessarily and unconditionally pro-Western, being critical of their former "home" countries foreign policies of democratic shortcomings. Overall, Armenian CSOs seem to romanticize "the West" less than they did in Georgia.

In the mid-2000s, Armenian civil society started to diversify and, in the process, became more responsive to the daily needs and lived experiences of the average Armenian citizen. Activist campaigns, called "civic initiatives," started to appear in Armenia, targeting specific issues such as, for example, preventing environmentally harmful mining projects (Stefes and Weingartner, 2015), saving public parks, preserving historic buildings, resisting an increase in transportation fees, and so on (Ishkanian, 2009). These were usually organized by young people, powered by social media, and framed as non-political. Unlike CSOs that often spoke in an alien sounding development jargon, activists spoke in plain (sometimes colloquial) Armenian about issues that were clear to everyone and tangibly impacted many.

Over the past decade, civic initiatives grew from being new to being commonplace. They became the default mode of struggle for many young people. Horizontal structures, spontaneity, flexibility, narrow focus, and relatively rapid outcomes (positive or negative results) make civic initiatives distinct from CSOs. Perhaps the biggest difference is in the use of finances. CSOs can hardly operate without grants. Civic initiatives refuse foreign funding and rely on resources their members can mobilize (Ishkanian et al., 2013). Taken together, civic initiatives and formal CSOs certainly make for a more diverse, and therefore more robust, adaptable, and energetic civil society, capable of representing more voices. Such civil society is likely to have more pronounced internal democratizing effects on its members and the population at large, creating opportunities to develop cooperation skills, public spiritedness and diverse social capital, needed for cross-cutting public mobilization.

Compared to Georgia, Armenian civil society on the verge of the Velvet Revolution was more rooted in the general public, less dependent on foreign funding, and more in sync with the concerns and daily experiences of the Armenian people. To the extent of its moderate capacities, it functioned as a watchdog of the state, but it also distanced itself from the political opposition (Zolyan, 2020; Paturyan and Gevorgyan, 2021). Until April 2018, Pashinyan did not have any visible 
support from CSOs and activists, except for his own small team of young, but largely unknown, people.

The Velvet Revolution started almost simultaneously in two different locations by two distinct groups. On March 24, 2018, a group of activists started a "Reject Serzh" protest in Yerevan. On 31 March, Nikol Pashinyan and his followers started a march from Gyumri, Armenia's second largest city (Baldryan, 2021). In mid-April, the two groups merged. Pashinyan's rhetoric and campaign style changed visibly after the merger, arguably due to the influence of his new allies (Paturyan 2020). From that point on, protests grew exponentially in size, attracting first young people and eventually including people from all walks of life, bringing the country to a standstill and forcing Serzh Sargsyan to resign.

During the 2 weeks of the uprising, both CSOs and informal activist groups became engaged in the networked resistance, but activists were more visible. They literally stood next to Pashinyan during rallies, and some were arrested. After the Velvet Revolution some prominent activists became members of the revolutionary government (Zolyan 2020), but compared to Georgia, their number was relatively small. More importantly, they were clearly inexperienced and not prepared to deal with an oversized, inert, but also fairly consolidated state apparatus. Compared to Georgia, Armenia's bureaucracy was professional, and therefore much harder to quickly take over and dismantle. The few civil society members who entered the government after the Revolution faced an uphill battle, trying to reform the state apparatus. It was a battle they were not prepared for. Some quit, some were fired, and a few have remained, learning the ropes. Unlike Georgia, the current Armenian government is mostly run by politicians, willing to listen to CSO advice, but only as long as that advice matches with their own political agenda.

Moreover, the Armenian revolutionary government faces substantial criticism both from civil society and from the former-government-turned-opposition forces. For example, environmental activists and local residents continue to block the construction of the Amulsar gold mine, expecting the government to side with them. The government, however, has announced the continuation of the project, then walked back on this announcement, leaving the project in limbo, seemingly reluctant to make unpopular decisions (Kucera and Mejlumyan, 2019). Pashinyan's government also faces daily scathing criticism from political opposition, which uses its previously accumulated resources, including major media outlets. Several TV channels are owned by people economically or politically affiliated with the previous government. In the past, they engaged in self-censorship or supported their government cronies. Now, ironically, media freedom, combined with low level of professionalism, lackluster commitment to journalism ethics, and political partisanship, produces unprecedented levels of government criticism.

Before the Velvet Revolution, Armenian civil society was focused on activities related to the external effects of civil society on democracy. However, the impact of civil society on the state was limited by the state's ability to resist pressure.
Nonetheless, Armenian CSOs developed policy and advocacy capacity they now use to engage with the post-revolutionary government. Most of that engagement is cordial, but there is also criticism. Armenian civil society did not merge with the postrevolutionary state, as was the case in Georgia. As a result, it is better placed to perform its watchdog function.

A contrast with Georgia is even starker when we consider the internal effects of civil society on democracy. In the years preceding the Velvet Revolution Armenian civil society was more successful in connecting to the broader public, building social capital, honoring its commitment to nonviolence, developing cooperation skills, visibly addressing issues of public concern and therefore acting as a "school of democracy" that connects people to each other and asserts their right to demand government accountability. As a result, CSOs and activists were able to mobilize large crowds when they chose to support Pashinyan in spring 2018.

\section{CONCLUSION}

In sum, until a few years ago, Georgia's civil society failed to develop deep roots in the general public. Georgia's CSOs did not see themselves as representatives of Georgian citizens, but as the country's avant-garde. Heavily funded by Western donors, CSOs espoused (Western) ideals that were not widely supported. Yet, these ideals nicely aligned with the goals embraced by some of Georgia's political elite, especially politicians who had been trained in the West and later formed the opposition that toppled Shevardnadze. At the same time, Georgia's civil society did not diversify. It did not develop any meaningful social and environmental grassroots organizations.

Close cooperation between the political opposition and CSOs was therefore a natural outcome, as was the later cooptation of some of the most prominent CSO leaders by the Saakashvili regime. Georgia thereby lost an actor skilled in exercising vertical accountability, allowing the hugely popular new president to amass power in his hands almost unrestrained. That some CSO leaders decided to join the government is not surprising. In some ways, they followed the money, as Western aid for civil society development dried up, being directed towards good governance projects. Furthermore, Georgia's utterly inept state bureaucracy was annoying, but it also provided the CSO leaders with a clean slate in pursuing a radical modernization of the country. They simply had to fire thousands of public officials and replace them with the country's best and brightest, which they did. Under these circumstances, Georgia's civil society could not push Saakashvili to strengthen the country's democratic institutions. Its internal and external effects on democracy were limited.

For almost 2 decades, Armenia's civil society mirrored the path of its Georgian counterpart, yet with three exceptions. First, it did not benefit nearly as much from Western aid as did Georgia's civil society. Second, it did not embrace Western ideals to the same degree as did Georgia's CSO leaders. Third, partially due to the first two reasons, it never developed a missionary zeal. As a result, it was later able to close ranks 
with the general public, especially when Armenia's civil society diversified with the rise of civic initiatives that addressed environmental and social concerns. Yet, Armenia's civil society kept a healthy distance from the organized political opposition, and when that political opposition replaced the authoritarian regime, only few civil society leaders joined the new government, arguably averting an inert and powerful state bureaucracy. Instead, Armenia's civil society has kept its equidistance to both the government and the opposition, which has allowed it to remain an important check on political power.

The U.S. Agency for International Development (USAID) largely agrees with our findings. Even after the revival of Georgia's civil society since 2012, Georgia's civil society still trails Armenia's civil society in USAID's 2019 Civil Society Organization Sustainability Index (CSOSI). The gap is not large and closing. Yet considering how much stronger Georgia's civil society was during the 1990s compared to the one in Armenia, it is clear that the Rose Revolution weakened, rather than strengthened, Georgia's civil society. Furthermore, the CSOSI indicates that Armenia's civil society clearly caught up with its Georgian counterpart during the 2000s and 2010s (USAID 2020).

The developments that we have described in this study are difficult to aggregate into hard data. Indices that measure civil society strength, including the CSOSI, should therefore be taken with a grain of salt. What we can say is that in the case of Georgia, Western donors did not provide much incentive for sustainable civil society development. Instead, they nurtured a civil society avant-garde that was later coopted by the new leadership which

\section{REFERENCES}

Abrahamian, L., and Shagoyan, G. (2011). From Carnival Civil Society toward a Real Civil Society: Democracy Trends in Post-Soviet Armenia. Anthropol. Archeology Eurasia 50 (3), 11-50.

Abrahamyan, L. (2001). "Civil Society Born in the Square: The Karabagh Movement in Perspective," in The Making of Nagorno-Karabagh. Editor L. Chorbajian (London: Palgrave Macmillan), 116-134.

Aliyev, H. (2015). Examining the Use of Informal Networks by NGOs in Azerbaijan and Georgia. J. Civil Soc. 11 (3), 317-332. doi:10.1080/ 17448689.2015.1069524

Anable, D. (2006). The Role of Georgia's Media-and Western Aid-In the Rose Revolution. Harv. Int. J. Press/Politics 11 (3), 7-43. doi:10.1177/1081180X06289211

Anheier, H. K. (2004). Civil Society: Measurement, Evaluation, Policy. Sterling, VA: Earthscan Publications.

Arellano-López, S., and Petras, J. F. (1994). Non-Governmental Organizations and Poverty Alleviation in Bolivia. Dev. Change 25 (3), 555-568. doi:10.1111/j.14677660.1994.tb00526.x

Astourian, Stephan H. (2000). "From Ter-Petrosian to Kocharian: Leadership Change in Armenia," in Working Paper. Berkeley Program in Soviet and PostSoviet Studies (Berkeley: University of California). https://escholarship.org/uc/ item/0c2794v4.

Baldryan, Sona. (2021). "Application of Rational Choice Theory to Armenia's Velvet Revolution.” Master's Thesis. Yerevan, Armenia: American University of Armenia.

BBC (2021). Georgia: Cameraman Dies after Attack at Anti-pride March. sec. Europe. London: ” BBC News. Available at: (Accessed July 11, 2021).

Beissinger, M. R. (2007). Structure and Example in Modular Political Phenomena: The Diffusion of Bulldozer/Rose/Orange/Tulip Revolutions. Perspect. Polit. 5 (2), 259-276. doi:10.1017/s1537592707070776 was undoubtedly Western-oriented, but nevertheless not deeply committed to democracy. At that point, Georgia's CSOs were in no position to stop Saakashvili from concentrating power in the presidency and thereby weakening democratic institutions. Today, some CSOs might be better placed to serve as defenders of democratic institutions and values, in opposition to the state, but also in conflict with a powerful non-state actor, the Georgian Orthodox Church.

In contrast, Armenia's civil society was not a prime beneficiary of the largess of Western democracy promotion. In many ways, this lack of foreign funding has allowed it to develop in more genuine ways and with closer connections to the larger public. It therefore maintains a healthy distance from the political elite, and it continues to be an important element of vertical accountability.

\section{DATA AVAILABILITY STATEMENT}

Publicly available datasets were analyzed in this study. This data can be found here: https://www.v-dem.net/en/data/data/v-demdataset-v111/.

\section{AUTHOR CONTRIBUTIONS}

The workload for this paper was equally shared. YJP was largely responsible for the theoretical framework and the Armenian case study. CHS was responsible for the Georgian case study, introduction, and conclusion.

Berman, S. (1997). Civil Society and the Collapse of the Weimar Republic. World Pol. 49 (3), 401-429. doi:10.1353/wp.1997.0008

Bernhard, M. (1993). Civil Society and Democratic Transition in East Central Europe. Polit. Sci. Q. 108, 307-326. doi:10.2307/2152014

Berry, J. M. (1999). “The Rise of Citizen Group," in Civic Engagement in American Democracy and. Editors T. Skocpol and M. P Florina (Washington, D.C.: Brookings Institution Press), 367-393.

Bieber, F. (2003). "The Other Civil Society in Serbia - Non-governmental Nationalism - the Case of the Serbian Resistance Movement," in Uncivil Society? Contentious Politics in Post-Communist Europe. Editors P. Kopecký and C. Mudde (London and New York: Routledge), 19-36.

Broers, L. (2005). After the 'revolution': Civil Society and the Challenges of Consolidating Democracy in Georgia. Cent. Asian Surv. 24 (3), 333-350. doi:10.1080/02634930500310444

Broers, L. (2020). ““Introduction: An Unlikely Transition?,” in Armenia's Velvet Revolution: Authoritarian Decline and Civil Resistance in a Multipolar World. Editors A. Ohanyan and L. Broers (London: I.B. Tauris), 1-23.

Bunce, V., and Wolchik, S. (2009). Debating the Color Revolutions: Getting Real about" Real Causes". J. Democracy 20 (1), 69-73. doi:10.1353/jod.0.0093

Carroll, T., and Carroll, B. W. (2004). The Rapid Emergence of Civil Society in Botswana. Commonw. Comp. Polit. 42 (3), 333-355. doi:10.1080/ 1466204042000326172

Cheterian, V. (2008). Georgia's Rose Revolution: Change or Repetition? Tension between State-Building and Modernization Projects. Natl. Pap. 36 (4), 689-712. doi:10.1080/00905990802230530

Clemens, E. S. (1999). "Organizational Repertories and Institutional Change: Women's Groups and the Transformation of American Politics, 1890-1920," in Civic Engagement in American Democracy. Editors T. Skocpol and M. P. Florina (Washington, D.C.: Brookings Institution Press).

Cohen, J. L., and Arato, A. (1994). Civil Society and Political Theory. Cambridge and London: The MIT Press. 
Coleman, J. S. (1990). Foundations of Social Theory. Cambridge and London: Harvard University Press.

Conference of INGOs of the Council of Europe. (2020). "Civil Participation in the Decision-Making Process: Fact Finding Visit to Armenia." Available at: https:// rm.coe.int/report-visit-of-the-conference-of-ingos-to-armenia-2019/16809ed448.

Coppedge, M., Gerring, J., Knutsen, C. H., Lindberg, S. I., Jan, T., Altman, D., et al. (2021). "V-Dem Codebook V11." Varieties of Democracy (V-Dem) Project. Available at: https://www.v-dem.net/media/filer_public/be/11/be11d657-a2404fb0-a47f-bc151296e779/codebook.pdf.

Coppedge, M., Gerring, J., Knutsen, C. H., Lindberg, S. I., Jan, T., Marquardt, K. M., et al. (2020). "V-Dem Methodology V10." Varieties of Democracy (V-Dem) Project. Available at: https://www.v-dem.net/media/filer_public/94/87/ 94876a61-1682-4227-baa0-ab927645d507/method.pdf.

Diamond, L. (1999). Developing Democracy: Toward Consolidation. Baltimore and London: The Johns Hopkins University Press.

Edwards, M. (2013). Civil Society. Cambridge, UK: Polity Press.

Eliasoph, N. (2003). "Cultivating Apathy in Voluntary Associations," in The Values Of Volunteering: Cross-Cultural Perspectives. Editors P. Dekker and L. Halman (New York: Springer), 199-212. doi:10.1007/978-1-4615-0145-9_12

FairbanksJr., and Charles, H. (2014). Georgian Democracy: Seizing or Losing the Chance? J. Democracy 25 (1), 154-165. doi:10.1353/jod.2014.0014

FairbanksJr., Gugushvili, A., and Gugushvili., A. (2013). A New Chance for Georgian Democracy. J. Democracy 24 (1), 116-127. doi:10.1353/ jod.2013.0002

Fowler, A., and Biekart, K. (2013). Relocating Civil Society in a Politics of CivicDriven Change. Dev. Pol. Rev. 31 (4), 463-483. doi:10.1111/dpr.12015

Fowler, A. (1997). Striking a Balance: A Guide to Enhancing the Effectiveness of Non-governmental Organisations in International Development. London: Earthscan Publications Ltd.

Fung, A. (2003). Associations and Democracy: Between Theories, Hopes, and Realities. Аnпu. Rev. Sociol. 29, 515-539. doi:10.1146/ annurev.soc.29.010202.100134

Geremek, B. (1996). "Civil Society Then and Now.," in The Global Resurgence of Democracy. Editors L. Diamond and M. F. Plattner (Baltimore and London: The Johns Hopkins University Press), 241-250.

Habermas, J. (1996). Between Facts and Norms - Contributions to a Discourse Theory of Law and Democracy. Cambridge and London: The MIT Press.

Henderson, S. L. (2002). Selling Civil Society. Comp. Polit. Stud. 35, 139-167. doi:10.1177/0010414002035002001

Howard, M. M. (2003). The Weakness of Civil Society in Post-Communist Europe. Cambridge UK: Cambridge University Press.

Ishiyama, J., Mezvrishvili, L., and Zhgenti, N. (2018). An Oasis of Democracy in an Authoritarian Sea? Civil Society, Social, and Institutional Trust in Georgia. Communist Post-Communist Stud. 51 (1), 19-26. doi:10.1016/ j.postcomstud.2018.01.005

Ishkanian, A. (2008). Democracy Building and Civil Society in Post-Soviet Armenia. London and New York: Routledge.

Ishkanian, A., Gyulkhandanyan, E., Manusyan, S., and Manusyan, A. (2013). "Civil Society, Development and Environmental Activism in Armenia," in The London School of Economics and Political Science (London: LSE). http:// eprints.lse.ac.uk/54755/.

Ishkanian, A. (2009). (Re)Claiming the Emancipatory Potential of Civil Society: A Critical Examination of Civil Society and Democracy Building Programs in Armenia since 1991. Armenian Rev. 51, 9-34.

Jacob, P. (2021). "Critically Endangered Sturgeons Threatened by Proposed Dams in Caucasus.” National Geographic, Available at: https://www.nationalgeographic. com/animals/article/dams-threaten-last-sturgeon-spawning-grounds-rioni-rivergeorgia. (Accessed June 7, 2020).

Jones, S. F. (2000). Democracy from below? Interest Groups in Georgian Society. Slavic Rev. 59 (1), 42-73. doi:10.2307/2696904

Jones, S. F. (2006). The Rose Revolution: A Revolution without Revolutionaries? Cambridge Rev. Int. Aff. 19 (1), 33-48. doi:10.1080/09557570500501754

Julie Hemment, J. (2012). Nashi, Youth Voluntarism, and Potemkin NGOs: Making Sense of Civil Society in Post-Soviet Russia. Slavic Rev. 71 (2), 234-260. doi:10.5612/slavicreview.71.2.0234

Kaldor, M., Kostovicova, D., and Said, Y. (2007). "War and Peace: The Role of Global Civil Society," in Global Civil Society 2006/7. Editors M. A. Kaldor, H. Anheier, and M. Glasius (London, etc.: Sage Publications).
Karatnycky, A., and Ackerman, P. (2005). "How Freedom Is Won: From Civic Resistance to Durable Democracy." Freedom House. Available at: https:// freedomhouse.org/sites/default/files/How\%20Freedom\%20is\%20Won.pdf.

Keane, J. (2005). Eleven Theses on Markets and Civil Society1. J. Civil Soc. 1 (1), 25-34. doi:10.1080/17448680500166098

King, C. (2009). "A Rose Among Thorns: Georgia Makes Good.” Foreign Affairs March/April (January). Available at: https://www.foreignaffairs.com/articles/ russia-fsu/2004-03-01/rose-among-thorns-georgia-makes-good.

Knack, S. (2004). Does Foreign Aid Promote Democracy? Int. Stud. Q 48 (1), 251-266. doi:10.1111/j.0020-8833.2004.00299.x

Knox, C., and Yessimova, S. (2015). State-Society Relations: NGOs in Kazakhstan. J. Civil Soc. 11 (3), 300-316. doi:10.1080/17448689.2015.1058322

Kopecký, P., and Mudde, C. (2003). Uncivil Society? Contentious Politics in PostCommunist Europe. London and New York: Routledge.

Kucera, J., and Mejlumyan, A. (2019). Pashinyan Allies Lament Slow Pace of Change in the New Armenia. EurasiaNet. Available at: https://eurasianet.org/ pashinyan-allies-lament-slow-pace-of-change-in-the-new-armenia (Accessed October 14, 2019).

Kupatadze, A. (2016). Georgia's Break with the Past. J. Democracy 27 (1), 110-123. doi:10.1353/jod.2016.0003

Kupchan, C. A. (2006). "Wilted Rose." the New Republic, Available at: https:// newrepublic.com/article/104849/wilted-rose.(Accessed February 6, 2006).

Lewis, D. (2001). The Management of Non-governmental Development Organizations. London and New York: Routledge.

Linz, J. J., and Alfred Stepan (1996). Problems of Democratic Transition and Consolidation. Southern Europe, South America, and Post-Communist Europe. Baltimore and London: Johns Hopkins Univ. Press.

Lomsadze, G. (2019). EurasiaNet. Available at: https://eurasianet.org/georgianprotesters-regroup-insist-on-cultured-approach (Accessed November 22, 2019). Georgian Protesters Regroup, Insist on Cultured Approach.

Way, L. (2008). The Real Causes of the Color Revolutions. J. Democracy 19 (3), 55-69. doi:10.1353/jod.0.0010

Malena, C., and Finn Heinrich., V. (2007). Can We Measure Civil Society? A Proposed Methodology for International Comparative Research. Dev. Pract. 17 (3), 338-352. doi:10.1080/09614520701336766

Mazlish, B. (2005). The Hi-Jacking of Global Society? an Essay. J. Civil Soc. 1 (1), 5-17. doi:10.1080/17448680500166031

McIlwaine, C. (1998). Contesting Civil Society: Reflections from El Salvador. Third World Q. 19 (4), 651-672. doi:10.1080/01436599814181

Mercer, C. (2002). NGOs, Civil Society and Democratization: A Critical Review of the Literature. Prog. Dev. Stud. 2 (1), 5-22. doi:10.1191/1464993402ps027ra

Mitchell, L. A. (2009). Compromising Democracy: State Building in Saakashvili's Georgia. Cent. Asian Surv. 28 (2), 171-183. doi:10.1080/02634930903034864

Mitchell, L. (2004). Georgia's Rose Revolution. Curr. Hist. 103, 342-348. doi:10.1525/curh.2004.103.675.342

Mkrtchyan, N. (2019). "The Armenian Apostolic Church between the State and Civil Society: Challanges and Opportunities," in In Armenian Developments: Perspectives of Democratization and the Role of the Civil Society Bonner Studien Zum Globalen Wandel 24. Editors W. Hilz and S. Minasyan (Baden-Baden: Tectum Verlag), 101-117.

Moyser, G., and Parry, G. (1997). "Voluntary Associations and Democratic Participation in Britain," in In Private Groups and Public Life European Political Science Series. Editor J. V. Deth (London and New York: Routledge), 24-46.

Muskhelishvili, M., and Jorjoliani, G. (2009). Georgia’s Ongoing Struggle for a Better Future Continued: Democracy Promotion through Civil Society Development. Democratization 16 (4), 682-708. doi:10.1080/13510340903083000

Myant, M. (2005). Klaus, Havel and the Debate over Civil Society in the Czech Republic†. J. Communist Stud. Transit. Polit. 21 (2), 248-267. doi:10.1080/ 13523270500108758

Ohanyan, A. (2020). "Velvet Is Not a Colour: Armenia's Democratic Transition in a Global Context," in Armenia's Velvet Revolution: Authoritarian Decline and Civil Resistance in a Multipolar World. Editors L. Broers and A. Ohanyan (London: I.B. Tauris), 25-49.

Paturyan, Y. (2020). "Armenian Civil Society: Growing Pains, Honing Skills and Possible Pitfalls," in Armenia's Velvet Revolution: Authoritarian Decline and Civil Resistance in a Multipolar World. Editors A. Ohanyan and L. Broers (Heidelberg: I.B. Tauris), 101-118. 
Paturyan, Y., and Gevorgyan, V. (2021). Armenian Civil Society. Societies and Political Orders in Transition. Springer International Publishing. doi:10.1007/ 978-3-030-63226-7

Putnam, R. D., Leonardi, R., and Nanetti, R. (1994). Making Democracy Work. Civic Traditions in Modern Italy. Princeton, N.J: Princeton University Press.

Putnam, R. D. (2000). Bowling Alone: The Collapse and Revival of American Community. New York: Simon \& Schuste.

Robson, E. (2011). "Media Freedom in Armenia: One Step Forward, Two Steps Back," in Spotlight on Armenia. Editor H. Adam (Cardiff: The Foreign Policy Centre), 21-25. http://fpc.org.uk/fsblob/1331.pdf.

Ruth Mandel, R. (2012). Introduction: Transition to where? Developing PostSoviet Space. Slavic Rev. 71 (2), 223-233. doi:10.5612/slavicreview.71.2.0223

Salamon, L. M., Wojciech Sokolowski, S., and Haddock, M. A. (2017). Explaining Civil Society Development: A Social Origins Approach. Baltimore: Johns Hopkins University Press.

Schmotz, A. (2015). Vulnerability and Compensation: Constructing an Index of Cooptation in Autocratic Regimes. Eur. Polit. Sci. 14 (4), 439-457. doi:10.1057/ eps. 2015.62

Skocpol, T. (1999). "How Americans Became Civic," in Civic Engagement in American Democracy. Editors T. Skocpol and M. P Florina (Washington, D.C.: Brookings Institution Press), 27-81.

Stefes, C. H. (2006). Understanding Post-Soviet Transitions: Corruption, Collusion and Clientelism. New York: Palgrave Macmillan.

Stefes, C. H. (2002). "The Incompatibilities of Institutionalized Corruption and Democracy in the Former Soviet Union: The Case of Georgia. Denver: Dissertation, University of Denver. Available at: https://search.proquest.com/ docview/304796321?pq-origsite=primo.

Stefes, C. H., and Weingartner., K. (2015). "Environmental Crime in Armenia: A Case Study on mining." A Study Compiled as Part of the EFFACE Project. Berlin: Ecologic Institute. https://www.ecologic.eu/sites/default/files/presentation/ 2015/stefes-15-efface_environmental_crime_in_armenia_1.pdf.

Tavits, M. (2006). Making Democracy Work More? Exploring the Linkage between Social Capital and Government Performance. Polit. Res. Q. 59 (2), 211-225. doi:10.1177/106591290605900204

Tevzadze, G. (2003). "Key Civil and Public Institutions and Values of Modern Georgia," in Discussion Paper 1. Building Democracy in Georgia. Attempts to Establish Democracy in Georgia (Washington, DC: International Institute for Democracy and Electoral Assistance).

Tocqueville, A. D. (2007). [1864]. Democracy in America. Stilwell: Digireads.Com. Tusalem, R. F. (2007). A Boon or a Bane? the Role of Civil Society in Third- and FourthWave Democracies. Int. Polit. Sci. Rev. 28 (3), 361-386. doi:10.1177/0192512107077097
USAID (2020). 2019 Civil Society Organization Sustainability Index: Central and Eastern Europe and Eurasia. Washington, DC: "United States Agency for International Development. Available at: https://www.fhi360.org/resource/ civil-society-organization-sustainability-index-reports.

V-Dem Institute. (2021). "V-dem: Global Standards, Local Knowledge." 2021. Available at: https://www.v-dem.net/en/.

Verba, S., Lehman Schlozman, K., and Brady, . E. (1995). "Voice and Equality," in Civil Voluntarism in American Politics (Cambridge and London: Harvard University Press). doi:10.2307/j.ctvlpnclk7

Voicu, M., and Voicu, B. (2003). "Volunteering in Romania: A Rara Avis.," in The Values of Volunteering: Cross-Cultural Perspectives. Editors P. Dekker and L. Halman (New York: Springer), 143-159.

Warren, M. E. (2001). Democracy and Association. Princeton and Oxford: Princeton University Press.

Welzel, C., Inglehart, R., and Deutsch, F. (2005). Social Capital, Voluntary Associations and Collective Action: Which Aspects of Social Capital Have the Greatest 'civic' Payoff? J. Civil Soc. 1 (2), 121-146. doi:10.1080/ 17448680500337475

Wheatley, J. (2010). Civil Society in the Caucasus: Myth and Reality. Caucasus Anal. Dig. 12, 2-6.

Zolyan, M. (2020). “Thirty Years of Protest: How Armenia's Legacy of Political and Civic Protests Prepard the Velvet Revolution," in Armenia's Velvet Revolution: Authoritarian Decline and Civil Resistance in a Multipolar World. Editors L. Broers and A. Ohanyan, 51.

Conflict of Interest: The authors declare that the research was conducted in the absence of any commercial or financial relationships that could be construed as a potential conflict of interest.

Publisher's Note: All claims expressed in this article are solely those of the authors and do not necessarily represent those of their affiliated organizations, or those of the publisher, the editors and the reviewers. Any product that may be evaluated in this article, or claim that may be made by its manufacturer, is not guaranteed or endorsed by the publisher.

Copyright (C) 2021 Stefes and Paturyan. This is an open-access article distributed under the terms of the Creative Commons Attribution License (CC BY). The use, distribution or reproduction in other forums is permitted, provided the original author(s) and the copyright owner(s) are credited and that the original publication in this journal is cited, in accordance with accepted academic practice. No use, distribution or reproduction is permitted which does not comply with these terms. 